\title{
Література:
}

1. Білецький О.І. Зібрання праць у 5 т. Т.2. Київ, 1965.

2. Білоус П.В. Мотив подорожі в "Енеїді" І.П. Котляревського. І.П. Котляревський - перший класик нової украӥнської літератури: зб. статей. Ч. ІІ. Полтава, 1998. С. 7 - 9.

3. Білоус П. В. Паломницький жанр в українській літературі. Житомир, 1997.

4. Білоус П.В. Творчість В. Григоровича-Барського. Київ, 1985.

5. Котляревський I. Поетичні твори. Драматичні твори. Листи. Київ, 1982.

DOI https://doi.org/10.30525/978-9934-26-073-5-1-25

\section{МОРАЛЬНО-ЕСТЕТИЧНІ ЦІННОСТІ ЕПОХИ ЗМІН У ЦИКЛІ «ZEITBILDER» А. ФОН ДРОСТЕ-ГЮЛЬСХОФ}

\author{
Білоус Н. В. \\ старший викладач кафедри іноземних мов \\ Таврійського державного агротехнологічного університету \\ імені Дмитра Моторного \\ м. Мелітополь, Запорізька область, Україна
}

Аннетте фон Дросте-Гюльсхоф (Annette von Droste Hulshoff, 1797-1848) є відомою письменницею та поетесою Німеччини ХIX ст. На сьогоднішній день творчість А. Дросте недостатньо проаналізовано вітчизняними, а в деяких аспектах - i зарубіжними вченими. Поетичний спадок видатної німецької поетеси маловідомий не тільки широкому колу читачів, а й навіть спеціалістам-філологам. Серед німецьких дростезнавців життя і творчість письменниці вивчали відомі германісти К. Буссе [1], К. Гезельгаус [2], В. Зільц [3], П. Берглар [4], В. Веслер [5], Ф. Зенгле [6], В. Геден [7], Р. Шнайдер [8]. Серед літературознавцівгерманістів інших країн слід відзначити студії Дж. Роллстона [9], Г. Пикар [10], А. Бакалова [11], О. Іванової [12]， Л. Колаго [13] та особливо нашого співвітчизника Б. Завідняка [14].

Одним з найбільш плідних періодів у творчості А. Дросте був кінець 1841 - початок 1842 року, коли було написано цикл «Zeitbilder» (у перекладі - «Картини епохи»). Представлений цикл $\epsilon$ серією $з$ десяти віршів, у яких авторка виявляє критичне налаштування на дискусіюбесіду зі своїми сучасниками. За допомогою новаторських текстів вона 
висловлює своє ставлення до політичної боротьби періоду Реставрації. Однак, мова у меншій мірі йде про висвітлення конкретних деталей політичних і соціальних проблем, які Дросте сприймає як несуттєві, другорядні. Натомість iї інтерес концентрується на основних питаннях суспільної самоідентифікації людини і ії поведінки 3 погляду етики індивідуума. У циклі Дросте окреслює своє ставлення до боротьби ідеологічних течій свого часу не у прямій конфронтації з ліберальною та революційною тенденційною поезією, а через виваження всіх поетичних напрямів нового часу, які представляли ці тенденції, оскільки «для поетеси, яка мало цікавилася теоретичними викладеннями, література була першочерговим засобом» висловити себе [15, с. 275].

Цикл 《Zeitbilder» містить поетичні твори повчального характеру, послання і притчові сюжети віддзеркалюють особистість поетеси, яку турбують байдужість до віри, забуття людських цінностей, необачність і нігілізм. Дросте визнає свою приналежність до епохи змін, але сподівається на розвиток успадкованих традицій і формування молодим поколінням власного амбітного світосприйняття.

У вірші «Vor vierzig Jahren» 3 циклу «Zeitbilder» можна виділити декілька основоположних образів, кожен з яких розкривається завдяки добору слів певного семантичного поля. У перших чотирьох строфах вірша ключовим посилом майстрині слова $є$ образ ностальгії, утворений рядом абстрактних іменників: ein Sehnen - «туга», ein Hoffen - «надія», ein Glühn - «бажання», та прикметників: mild - м'який, frisch - свіжий, kräftig - сильний, schamhaft - соромливий, які характеризують минулу епоху як м'яку, свіжу, чисту та сором'язливу. Можна побачити у вірші i повторювані семи: lieb - коханий, der Lieb - закоханий, Lieb - любов. Також образ ностальгії розвивається від зворотного за допомогою заперечення: «Da lachte nicht» i негативного префікса un: unbekannte (непізнаний, незнаний) Gott, що створюють характеристику простодушності і наївної набожності. Посилання до наївної чистої віри розкриває образ ностальгії і завдяки релігійним реаліям: Gott - бог, die Altäre - вівтар, Glut - пекло, Weihrauch - ладан, Eden - рай.

Останнім за згадуванням в описі буття минулих років і тим самим найважливішим за значенням $\epsilon$ аспект правдивої творчості. Його представляють іменникові словосполучення, де іменник у Genitiv характеризує ключові поняття: Herzens Odem, der Begeistrung Ode, der Lieb Ekloge, тобто творчість для поетеси прирівнюється до дихання i серцебиття. Щирість життєво необхідна для Дросте, і поетеса черпає іiї у минулій епосі. Глибока любов і ніжність як основні характеристики ностальгії є джерелом натхнення поета, життєвим і творчим орієнтиром. 
Образ теперішнього є вкрай суперечливим. 3 одного боку поетеса засуджує прогресивне століття, яке прийшло на зміну романтичній епосі, і яке привнесло нігілізм, прагматизм: Schätze - скарби, Stahl - сталь, Stein - камінь та загальне захоплення сарказмом: höhnen - висміювати, lachen - сміятися, Spott - насмішка. 3 іншого боку поетеса усвідомлює масштабність впливу науково-технічного прогресу i роль людини як активного споживача його привілеїв: Weiten offen - відкриті широти, Ferne nah - даль близька, Geistesflug - політ думок, Dampf - пар, Fremdes erfassen - забирати у іноземців. Проте поетеса не приховує свого презирства до прихильників подібних змін: machen wie Strauße wir uns breit - відчувати себе як страуси в пустелі, Eises Gletscher глетчер льоду, Basiliskenblick - погляд василіска, bettelhafte Kön'ge жебрацькі королі.

Ключовим моментом у створенні образу сучасності $\epsilon$ семантичне поле порожнечі. Відкриті широти і близькі далі сусідують з ураганами, садами-маревами (Morgana’s Gärten), степовою імперією, де ідеал зникає як вода в пісок (zerrint). Образ духовної пустоти та бідності як жебрацтва розкривають прикметники: arm - бідний, klein маленький, kalt холодний, leer - порожній, bleich - блідий та bettelhaft - жебрацький.

Сучасна поетесі людина - це мандрівник пустелею у вічній гонитві за матеріальним, який не усвідомлює свою убогість, не лякається пустого та холодного майбутнього. Особливої глибини віршу надає протиставлення духовного та приземленого: семантичні поля віри, любові та творчості для створення образу минулої епохи більш виразні, ніж реальність. Цикл «Die Zeitbilder», який сама поетеса вважала гідним, втілив у літературній формі протистояння поетеси тенденційній поезії і вимушено поставив іiі у позицію протистояння з поширювачами ліберальних ідей [15, с. 286].

Виходячи з вище зазначеного слід наголосити, що окрім літературної та естетичної цінності цикл «Zeitbilder» відзначається глибокою моральною ідеєю, настановою без нав'язливості, які висловлено, детально сформовано і викладено у вигляді гармонійної композиції з сюжету, системи образів, міфообразів та семантичних засобів. Беззаперечно, картина світу, яку Дросте бачила виходячи зі свого власного сприйняття дійсності, цікава як для читачів, так і для літературознавців протягом багатьох десятків років. Незважаючи на те, що цикл «Zeitbilder» створений у віддалений від нас час і представляє іншу культуру, інші суспільні норми і особистісні амбіції, урочистий і піднесений колорит цих віршів має своєрідний емоційний вплив на бачення світу і в наш час, оскільки людські цінності, до яких звертається і які звеличує Дросте, вічні. 


\section{Література:}

1. Busse C. Annette von Droste-Hülshoff. Eine Biografie. Köln : Severus, 2014. $176 \mathrm{~S}$.

2. Heselhaus C. Annette von Droste-Hülshoff. Die Entdeckung des Seins in der Dichtung des 19. Jahrhunderts. Halle [Saale] : Max Niemeyer, 1943. S. 45.

3. Silz W. The Poetical character of Annette von Droste-Hülshoff (1797-1848). PMLA.1948. 63. S. 978.

4. Berglar P. Annette von Droste-Hülshoff in Selbstzeugnissen und Bilddokumenten. Reinbek bei Hamburg : Rowohlt, 1967. 189 S.

5. Woesler W. "Die Droste und das "Feuilleton" der "Kölnischen Zeitung", Kleine Beiträge zur Droste-Forschung 1971. Zahnstein: Nohr; Münster: Stenderhoff in Komm, 1970.

6. Sengle F. Biedermeierzeit. Deutsche Literatur im Spannungsfeld zwischen Restauration und Revolution 1816-184. In 3 Bd. Stuttgart, 19721980. $1162 \mathrm{~S}$.

7. Gödden W. Annette von Droste-Hülshoff - Ihr Leben, ihr Wesen, ihr Werk. Gödden W. Wie sie lebte Wie sie war Was sie schrieb. Münster, 1990. S. $13-43$.

8. Schneider R. Das künstlerische Selbstverständnis der Droste im Horizont ihrer Zeit. Schneider R. Annette von Droste-Hülshoff (1797-1848) "aber nach hundert Jahren möcht ich gelesen werden". Wiesbaden, 1997. S. $3-11$.

9. Rolleston J. Narratives of Ecstasy: Romantic Temporality in Modern German Poetry. Zürich : Arche Verlag, 1987. 248 S.

10. Pickar G. B. "Too manly is your spirit": Annette von DrosteHulshoff. URL: https://scholarship.rice.edu/bitstream/handle/1911/63308/ article_RIP641_part5.pdf?sequence=1 (дата звернення: 25.11.2012).

11. Бакалов А. С. Немецкая послеромантическая лирика (традиции и новаторство) : дис....д-ра. филолог. наук: 10.01.03. Москва, 2004. 414 с.

12. Иванова Е.Р. Литература немецкого бидермейра [Электронный ресурс]: учеб. пособие. Москва : ФЛИНТ, 2012. 139 с.

13. Kolago L. Die Dichterin Annette von Droste-Hülshoff als Komponistin. Frankfurt : Peter Lang GmbH, Internationaler Verlag der Wissenschaften, 2013. $248 \mathrm{~S}$.

14. Завідняк Б. Духовна спадщина Аннети фон Дросте-Гюльсгоф. Всесвіт: журнал іноземної літератури. 2010. № 5/6. С. 225-232.

15. Kortländer B. Annette von Droste-Hülshoff und die deutsche Literatur. Bd.3. Münster in Westfalen, 1979. 384 S. 